\title{
Activities of the Society
}

\section{TITLES of the Reports Presented at the 30 th Meeting of \\ The Electrochemical Society of Japan Held at \\ The Tokyo Chamber of Commerce and \\ Industry On April 20 21, 1963}

\section{Corrosion and Anti-corrosion}

Corrosion Behaviours of Stainless Steels in Anhydrous Mineral Acids.

M. Mukai, T. Saji and H. Yoshimura

Corrosion of Coated Steel Plates.

K. Yamamoto, H. Okada and K. Inoue

Desorption Rate of Bound Water in the Passive Film Formed on Stainless Steels.

T. Shibata and G. Okamoto

Effects of Temperature on the Growth of Passive Film of Stainless Steels.

T. Ishikawa and G. Okamoto

Studies on the Oxidation of Binary Alloys. I. Cu-Ni and Au-Al Systems.

T. Mukaibo, K. Fueki, H. Ishibashi and H. Nishikado

Effect of Vacuum Annealing of Oxide Film on Oxidation Kinetics of $\mathrm{Cu}-\mathrm{Ni}$ Alloy.

T. Yamashina and T. Nagamatsuya

Thermogalvanic Corrosion of Aluminum.

T. Kishi, H. Saito, T. Nagai and T. Takei

Mechanism of Inhibition of Stannous Ion for Corrosion of Iron in Acidic Solution.

K. Matsunaga, and G. Okamoto

Impedance Measurement of Metals Under Potentiostatic Polarization. I. Apparatus and Procedure.

S. Morioka, Y. Sawada and K. Shiobara

On Corrosion and Inhibition of Aluminum by Viscoplastic Substances Prepared from Calcium Phosphate.

M. Izuyama and Y. Hayakawa

Studies on Thiourea Type Corrosion Inhibitors. I.

T. Yoshida and Y. Oji

$\beta$-Diketones as Inhibitor of Aluminum Alkaline Medium.

K. Horiguchi, T. Shimizu, T. Sone and Y. Hayakawa

\section{Batteries}

The Effect on Concentration of Chlorine Ion for Electrolytic Reduction of Silver Chloride in AIkaline Aqueous Solution. 
H. Ogawa, K. Asai, T. Hirai and Y. Amano

Discharge of Zinc Electrode in Alkaline Solutions.

K. Asai, H. Ogaiwa, T. Hirai and Y. Amano

Effect of Lithium on the Active Mass in Positive Plate of Alkali Storage Battery.

D. Yamashita and Y. Yamamoto

Polarization Characteristics of the Nitrate Nitrite Aqueous Solution.

T. Hata and H. Matsuoka

Study of a $\mathrm{Cu}-\mathrm{PbO}_{2}$ Battery Adopted a Cation Reversible Metallic Electrode.

S. Furumi, T. Kubo and H. Sakashita

The Effects of Various Additives on the Discharge Reaction of the Lead Dioxide Electrode.

S. Yoshizawa, Z. Takehara and S. Ichikawa

The Wetproofing Effect of the Carbon Electrode.

S. Yoshizaw'a, Z. Takehara and K. Fujita

Studies on the High Temperature Fuel Cell Using Fused Electrolyte.

S. Toshima, T. Murakami, N. Kimura and Y. Hata

Studies on the High Temperature Fuel Cell Using $\mathrm{ZrO}_{2}-\mathrm{CaO}$ Solid Electrolyte.

S. Toshima, T. Murakami, N. Kimura and Y. Hata

The Electric Conductivity of the Sintered Oxides. I. On the Ce-La System.

T. Takahashi, O. Yamamoto and H. Iwahara

Conductivity of Solid Electrolytes. IX. On the System of $\mathrm{AgI}-\mathrm{Ag}_{2} \mathrm{~S}$ (II).

T. Takahashi and O. Yamamoto

Durabilities of the Sintered-Type Nickel Positive Plate.

K. Sugita

On the Self-discharge of Hydrogen Fuel Cell.

M. Kubokawa, H. Yamazaki and G. Takeshima

Concentration Cell Using the Ion Exchange Membranes.

T. Matsuno, H. Onoue and R. Tsuchiya

Studies on Fuel Cells. IV. On the Internal Resistance of Ion-Exchange Membrane Fuel Cells.

T. Ishino, H. Tamura, J. Shiokawa and Y. Matsuda

Studies on Fuel Cells. V. Effects of Temperature on Ion-Exchange Membrane Fuel Cell Performance.

T. Ishino, H. Tamura, J. Shiokawa and Y. Matsuda

On the Characteristics of Hydrogen Oxygen Layer Built Type Fuel Cell.

S. Matsuno, Y. Kobayashi, K. Tomiie, S. Hayashi and K. Sawada

Polarization of Methanol Electrode.

S. Takahashi, S. Ninagi and Y. Miyake

The Cells with Organic Redox Compounds. III. 


\section{Extractive Metallurgy}

Studies on Extraction of Vanadium from Vanadium-containing Slag.

K. Asada, K. Atarashiya and M. Takatsuki

Studies for Decomposition of Xenotime.

T. Ishino, J. Shiokawa and G. Adachi

Mechanism of Electrolytic Deposition of Beryllium Metal from Beryllium Chloride Bath.

T. Kuroda and O. Matsumoto

Electrowinning of Chromium from Ferrochromium.

T. Nagai, T. Takei, H. Winterhager and R. Kammel

Study on the Extractive Metallurgy of Zirconium.

K. Funaki, H. Kojima and S. Watanabe

Studies on Metallurgy of $\mathrm{Al}$ by Disproportionation. I. Reaction Between $\mathrm{AlCl}_{3}$ and $\mathrm{Al}$.

T. Morinaga, T. Takahashi, I. Tanabe, H. Konno and Y. Sawada

Studies on the Metallurgy of $\mathrm{Al}$ by Disproportionation. II. Purification of $\mathrm{Al}$ from $\mathrm{Al}-\mathrm{Fe}-\mathrm{Si}$ Alloys.

T. Morinaga, T. Takahashi, I. Tanabe, H. Konno and Y. Sawada

Oxydation of Zinc Sulfide with Dissolved Oxygen in Acid Solutions.

Y. Hisamatsu and N. Masuko

Reduction of Uranyl Oxalate in Light.

K. Funaki, I. Ishijima, I. Matsuda and S. Yoshino

Studies on the Effects of Soluble Metals on the Anode Polarization of Copper.

S. Suzuki

Preparation of Anhydrous Yttrium Chloride.

S. Tanii

\section{Theoretical Electrochemistry and Industrial Physical Chemistry}

Studies on $\mathrm{Pd}-\mathrm{Au}-\mathrm{H}$ Electrodes.

T. Shirogami

Catalytic Mechanism of Hydrogen Electrode Reaction.

H. Shiratori

Reversible Oxygen Electrodes.

N. Watanabe and M.A. Devanathan

Fundamental Studies on the Solion. I \& II.

S. Asakura, H. Onoue and T. Matsuno

The Behaviour of Metallic Halides in Carbonaceous Materials.

T. Mukaibe, Y. Takahashi and Y. Hori 
Analysis of Current-Time Curves in the Potential Step Method.

S. Toshima, Y. Okinaka and H. Okaniwa

Current Density Distribution on a Reversible Solid Electrode in Polarography.

T. Nishi, T. Nishino and M. Ichise

Fluorine Evolution Reaction.

N. Watanabe, M. Inoue and S. Yoshizawa

On the Interfacial Double Layer of Aqueous Solutions Containing Butyne-2-Diol 1.4.

T. Yoshida and I. Sekine

Preparation of $\mathrm{SO}_{4}{ }^{2-}$ Impermeable Anion Exchange Membranes.

R. Yamane and Y. Mizutani

Studies on the Effects of Soluble Metals on the Anode Polarization of Copper.

S. Suzuki

Anomalous Ionic Conduction Across Ion-exchange Membranes.

M. Senoo and T. Yamabe

The Migration of Water Through the Anion and Cation Exchange Membranes.

H. Kisaki and T. Yano

Mechanism of Formation and Their Physical Properties of Thin Oxide Films on Metals and on Semiconductors. I. Physical Properties of the Oxide Films.

Y. Ishikawa and Y. Sasaki

Mechanism of Formaion and Their Physical Properties of Thin Oxide Films on Metals and on Semiconductors. II. Theory of Film Formation.

Y. Ishikawa and S. Inowaki

Mechanism of Formation and Their Physical Properties of Thin Oxide Films on Metals and on Semiconductors. III. Applications : Solid Electrolytic Capacitors for High Temperature Use.

Y. Ishikawa, E. Okamoto and S. Inowaki

Mechanism of Formation and Their Physical Properties of Thin Oxide Films on Metals and on Semiconductors. IV. Application : Solid Electric Cell for High Temperature Use.

Y. Ishikawa and Y. Seki

\section{Electro-deposition and Surface Treatment}

Effects of Addition Agents on the Electrodeposition of Copper.

W. Sakai, T. Seiyama and T. Mine

Study of High Speed Bright Copper Plating from Cyanide Bath.

Y. Kuwa, T. Suzuki and Y. Noda

Mechanism of Copper Deposition from Fluoborate Baths.

S. Yoshizawa, F. Hine, M. Tsuiki and Y. Ueno

Effect of Addition Agents in Electrodeposition of Nickel.

T. Hayashi, K. Hirooka and T. Ishida 
Determination of Fluorosilicate Ion in the Chrome-Plating Bath.

H. Imanaga

On the Silver Dendrites Electrocrystallised in the Sulfamate Bath.

M. Kikuchi and R. Yamazaki

Anodic Oxidation of $\mathrm{Fe}^{++}$Ion on the Passive Ion Electrode.

M. Nagayama and S. Kawamura

\section{High Temperature Chemistry and Fused Salts}

Sodium and Magnesium Reduction of Niobium Pentachloride.

Y. Saeki, G. Omori and T. Matsushima

Preparation of Silicon Nitride.

S. Takase and M. Noguchi

High Temperature Polaro-wave of Metal Compounds Dissolved in the Molten Bath, Using Platinum Micro-cathode.

Y. Taniyama, S. Arai and Y. Hayakawa

A Fundamental Study on Metal-fog.

M. Okada, K. Yoshida and Y. Hisamatsu

\section{Industrial Electrolysis}

Effects of the Cobaltous Ion for the $\mathrm{Cl}_{2}$-caustic Diaphragm Electrolysis.

O. Suzuki, T. Fukunaga and T. Matsuno

Effects of Some Impurities in Electrolysis of Chlorine Caustic by Mercury Process.

S. Mizuno, O. Furukawa, T. Iijima and Y. Samejima

The Inclination of Cell in the Mercury Cell.

S. Sawada and M. Tsunoi

Some Consideration on the Mechanism of Electrodeposition of Manganese Dioxide.

M. Mukai and M. Kuwa

On the Pt-Plated Electrode.

H. Yamamoto, Y. Kokubu, K. Nezu, T. Nagai and T. Takei

\section{Organic Electrochemistry}

Cathodic Process for the Electrolytic Reduction of Acetone-Mechanism of Hydrocarbon Formation.

A. Yamura, T. Sekine and K. Sugino

The Electrolytic Reduction of Acetyl Benzoyl.

T. Arai and C. Kitazawa

Polarography of Anthraquinone Derivatives.

W. Sakai, K. Kusunoki and I. Matsuo 
On the Transition Time of Anode Potential in the Kolbe's Reaction of Higher-fatty Acids.

R. Matsuda, T. Hisano, T, Terazawa and H. Ejima

Electrode Potential Measurements in Kolbe Electrosynthesis.

T. Hayashi, K. Tamura, Y. Fukumoto and T. Ishida

Mechanism of Kolbe Electrode Process of Acetic Acid-Acetate Mixture in Aqueous Solution. II. Anodic Reaction at $\mathrm{PbO}_{2}$ and other Insoluble Anodes.

T. Sekine, N. Sato, I. Dogane and K. Sugino

Oxidation and Adsorption of Alcohols on Platinum Electrode.

K. Ohashi, K. Asai, K. Sasaki and S. Nagaura

Anodic Reaction of Nitric Acid in Quasi-nonaqueous Solution-Reaction of Nitrate Free Radical with Organic Substances.

K. Sugino, K. Shirai and T. Nonaka

Accelerating Effect of High Frequency Electricity upon Esterfication.

K. Noguchi

\section{Electroanalysis}

Electrode Reaction of Dichromate Ion at Mercury Cathode.

S. Obara and T. Sekine

Polarography Using a Rotating Hanging Mercury Drop Electrode. II.

N. Ishibashi, S. Kamada, K. Nakayama and T. Seiyama

\section{Electronics and Materials for Electrical Industry}

Preparation and Magnetic Properties of $\mathrm{Co}-\mathrm{Ni}-\mathrm{P}$ Electrodeposits.

S. Umeki, M. Sato and Y. Hoshino.

Preparation of Thin Cobalt Recording Films Evaporated and Their Properties.

Y. Makino, M. Sato and Y. Hoshino.

Magnetic Properties and Recording Characteristics of $\mathrm{Fe}_{3} \mathrm{O}_{4}-\gamma-\mathrm{Fe}_{2} \mathrm{O}_{3}$ Tapes.

Y. Imaoka, S. Tochihara, M. Sato and Y. Hoshino.

On the Fine Ferrite Particles Prepared by Hydrothermal Method.

T. Takei, S. Tominaga and S. Saito

On the Fine Ferrite Particles Prepared by Hydrothermal Method.

T. Takei, S. Tominaga, H. Amari, T. Ojima and T. Oshima

Formation of Manganese Ferrite in Inert Gas Atmosphere.

T. Yamazaki, Y. Shimizu, K. Sakazaki and K. Funaki

Electrochemical Circuits Elements. I.

S. Mizuno and T. Yura

Selfheating Type Germanium Thermistor.

J. Yoshida and S. Ogawa 
Eptiaxial Growth of GaAs.

S. Kikuchi, T. Okada and T. Kano

Optical Memory Effect of Microcrystalline Zinc Oxides.

E. Inoue, I. Maki and K. Shoji

The Oxidation of Copper Thin Films.

K. Nakanishi and D. Yamada

Effects of Water Vapor on the Dark-current of Evaporated Cadmium Sulfide Films.

D. Yamada and K. Nakanishi

Electrical Conductivity of Black Mercuric Sulfide.

R. Tominaga and K. Takei

Thermo-electrical Motive Force of Black Mercuric Sulfide.

K. Takei and R. Tominaga 


\section{TITLES of the Reports Presented by the Members of The Electrochemical Society of Japan At the Fall Meeting Under the Auspices of The Electrochemical Society of Japan In Co-operation with Other 24 Chemical Societies and Associations in Japan Held at University of Tokyo On Nov. 2, 1963}

Differential Thermal Analysis of the Binary Systems in the System NaOH-NaCN-NaI.

S. Yoshizawa, Nobuatsu Watanabe and Youji Ohara

Relations Between Input Quantity of Electricity and Output Current in a Pair of Parallel-Plate Electrodes.

$$
\text { K. Asai, T. Hirai and M. Fukuda }
$$

Some Observations on the Nonuniformities in the Anodic Oxide Film of Tantalum.

H. Yoneyama, T. Hirai and M. Fukuda

Platinum Plating of Magnetite Electrodes.

Y. Kokubu, H. Yamamoto, T. Nagai and T. Takei

Thermogalvanic Corrosion of the System $\mathrm{Cu}_{-} \mathrm{CuSO}_{4}$ aq. Solutions.

$$
\text { K. Tomiya, Y. Makita, T. Niwa, T. Nagai and T. Takei }
$$

Magnetic Aging Effects and Recording Characteristics of $\mathrm{Fe}_{3} \mathrm{O}_{4}-\gamma-\mathrm{Fe}_{2} \mathrm{O}_{3}$ Tapes.

Y. Imaoka, M. Sato and Y. Hoshino

Magnetic Properties of Evaporated Iron Recording Films.

Y. Makino, M. Sato and Y. Hoshino

Recording Characteristics of Electrodeposited Magnetic Films.

S. Umeki, M. Sato and Y. Hoshino

On the Mercury Process for Persulphate Production by Electrolysis of Sodium Sulphate. V. Influence of Mercury Impurities on the Electrolysis.

S. Yoshizawa, F. Hine, M. Kubokawa and M. Yamashita

Thermodynamic Properties of Niobium Oxychloride.

Y. Saeki, T. Suzuki and T. Matsushima

Hydrogen Reduction of Niobium Pentachloride.

Y. Saeki and T. Suzuki

Decomposition of Niobium Pentachloride and Tantalum Pentachloride with Oxygen.

Y. Saeki and T. Matsushima

High Temperature Polaro-wave on the Molten Salt Using Micro-platinum Cathode.

Y. Kimura, S. Arai, and Y. Hayakawa 
Concentration of Sodium Sulphate Solution by Electrophoretic Dialysis Using Ion Exchange Membranes.

H. Kisaki and S. Mabuchi

Phase Diagram for the System $\mathrm{PbF}_{2}-\mathrm{SmF}_{3}$.

M. Sato and T. Utsunomiya

The Diffusion of Zinc in GaAs.

S. Kikuchi, H. Watanabe and M. Maruyama

Ferrite Core for Magnetic Recording Head.

F. Itoh, M. Namikawa, Y. Ando and S. Ota

Evaluation of the Life of the Fibre-Clud Type Storage Batteries.

S. Hisano

Electrochemistry of Troponoids.

J. Mizuguchi and T. Sato

Study of Fused Beryllium Chloride Sodium Chloride System by the Measurement of Decomposition Voltage.

T. Kuroda and O. Matsumoto

The Study of the Corrosion Inhibitors of Aluminum in Alkaline Solution.

M. Katoh and K. Tanaka

Corrosion Resistance of Tantalum in Condensed Phosphoric Acid.

T. Saji

The Influence of Magnetic Coating Thichness and $r-\mathrm{Fe}_{2} \mathrm{O}_{3}$ Content on Pulse Recording.

S. Tochihara, Y. Makino and F. Saito 


\section{TITLES of the Reports Presented at the 10th Corrosion Conference Sponsored by 15 Societies and Associations in Japan including the Electrochemical Society of Japan Held at Takarazuka Hotel, Takarazuka, Hyogo On Oct. 16 18, 1963}

\section{Symposium on Stress Corrosion}

The Stress Corrosion Cracking of High Strength Steel by Hydrogen Sulfide.

H. Sato, A. Umezono, R. Todoroki and K. Masuda

Stress Corrosion Cracking of High Strength Steels.

K. Inoue, H. Okada, Y. Hosoi, K. Yukawa and K. Tsuchiya

Studies on the Sulfide Corrosion Cracking of Welded High Strength Steels-On the Relation Between Hydrogen Embrittlement and Sulfide Corrosion Cracking.

S. Nishimura, S. Kurisu and M. Otani

Corrosion Cracking of High Strength Steel in LPG Storage Tanks.

H. Kihara

Stress Corrosion Cracking for High Tensile Steels.

M. Watanabe (Guest Speaker)

Electron-Microscopic Investigations of Stress Corrosion Cracking.

M. Takano and S. Shimodaira

Stress Corrosion Cracking of Stainless Steel Made Heat Exchanger Tubes.

Y. Sakae, K. Onimura and K. Mizutamari

Effects of Halogen Ions on Anodic Behavior of Stainless Steel.

T. Maekawa, N. Nakajima and M. Kagawa

On Stress Corrosion Cracking of $\mathrm{Ti}$ and $\mathrm{Zr}$ in $\mathrm{HCl}-\mathrm{Methanol} \mathrm{Solution.}$

T. Shimose and K. Mori

Corrosion of Steel in $\mathrm{NH}_{4} \mathrm{CN}$ and $\mathrm{H}_{2} \mathrm{~S}$ Solutions.

T. Inui, K. Hosokawa and K. Kurokawa

Low Cycle Corrosion-Fatigue Under Varying Load.

Y. Minami, H. Itagaki and I. Kudo 
Effect of Aging on the Acid Resistance of Precipitated Ferric Hydroxide.

G. Okamoto and R. Furuichi

Electronic Spectra of Molecules and Ions Adsorbed on Metal Surfaces in Aqueous Solutions.

W. Suetaka and S. Shimodaira

Relation Between the Rate of Temperature Change and Passivity-Maintaining Current.

G. Okamoto and T. Ishikawa

Studies on the Oxidation of Binary Alloys (II) The Mechanism of the Formation of the Internal Oxide Layer in $\mathrm{Cu}-\mathrm{Al}$ Alloy.

T. Mukaibo, K. Fueki, H. Ishibashi and M. Imaizumi

Independence Measurements of the Corrosion Film Formed on Aluminum.

S. Nomura and Y. Kondo

Refractive Index and Birefringence of Various Conversion Films on Aluminum.

S. Tajima and T. Mori

On the Mechanism of Cavitation Damage of Metals Subjected to Magnetstrictive Vibration.

S. Yoshizoe, T. Sato, K. Hashimoto and S. Shimodaira

Cavitation Corrosion Resistance of Metallic Coatings for Diesel Cylinder Liner.

S. Tsuyuki, K. Tarao and A. Fujii

Composition of Corrosion Products in Power Plant Boiler.

T. Hayashida, S. Miura, Y. Yamada and K. Yanagase

The Formation of Bonded Fireside Deposits in Pulverized Coal-fired Boilers of Thermal Power Station.

Y. Yamada

Sulfur Contents of the Crude Oil and Their Corrosivity.

M. Totsuka and T. Masuyama

Corrosion Phenomena on Galvanic Couple of Stainless Steel and Copper Alloys in Concentrated Brine.

K. Shimizu, N. Miyauchi and M. Ono

Electrochemical Studies on Condensor Corrosion by Polluted Water (II).

H. Sugawara, T. Sato and S. Shimodaira

The Effect of the Solution Containing Various Amino Acids or Their Salts on the Corrosion of Metals.

Y. Kitamura and J. Ito

Studies on the Corrosion of Stainless Steel in Organic Acid Solution (I) On Fe-Cr Alloys in Maleic Acid Solution.

K. Sakiyama and S. Hayashi

Estimation of Corrosion Rate of Buried Steel in Marine Environment.

N. Hanada, K. Zen and M. Toyobe

Electrolysis of Steel Piles Caused by Stray Current.

K. Hoshino 
Studies on the Atmospheric Corrosion of Steel Related with the Meteorological Elements in Japan (II).

$$
\text { K. Oma, T. Sugano, T. Ueki and Y. Hirai }
$$

The Study on the Corrosion Behavior of Fe-C Binary Alloys.

H. Ebiko and S. Shimodaira

Effect of Vacuum Annealing of the Oxide Films on Oxidation Kinetics (II) Effect of Composition of Alloys and the Thickness of Oxide Films.

T. Yamashina and T. Nagantatsuya

Corrosion of Wrought Iron.

K. Inoue, H. Okada, H. Naito, T. Ooka, R. Kusaka and H. Kido.

Studies on Cathodic Protection (I) Some Considerations of Potential Distribution on Plane.

T. Yoshii and K. Ueda

Studies on Cathodic Protection (II) Application of Potential Distribution Formula to Cathodic Protection.

T. Yoshii and K. Ueda

Application of Cathodic Protection to a Marine Ship.

T. Yoshii, K. Ueda and M. Yanagi

Cathodic Protection with Al Anode.

S. Takeshima, M. Ota and S. Tamari

Cathodic Protection of Piping System by Automatic Control.

H. Shigeno, H. Togano, T. Kobayashi, H. Nakauchi, Y. Kanda and K. Osato Anodic Protection of Austenitic Stainless Steel in Sulfuric Acid.

H. Togano, Y. Kanda and H. Shigeno

Studies on Reference Electrode for High Temperature and High Pressure Operations.

H. Shigeno, H. Nakauchi, and K. Osato

Studies on Amine-type Corrosion Inhibitors (XXVI) Similarity Between Corrosion Inhibitors and Catalyst Poison (VI).

S. Fujii and K. Kobayashi

Studies on Amine-type Corrosion Inhibitors (XXVII) Adsorption Mechanism of Inhibitors (III) Association and Adsorption of Inhibitors.

K. Aramaki and S. Fujii

Studies on the Thiourea Type Corrosion Inhibitors (II)

Y. Oji and T. Yoshida

Effect of Mercaptobenzothiazol on the Corrosion of Copper and Brass in Acid Solutions.

T. Kobayashi

Effect of Minor Constituents in Mild Steel on the Inhibitive Action of Stannous Ion.

G. Okamoto, K. Matsunaga and K. Inoue

Investigation of Sodium Nitrite as Aluminum Corrosion Inhibitor in Neutral Aqueous Solution. 


\section{Symposium on Surface Finishing and Protection}

Evaluating Methods for Application of Rust-Preventive Paints.

Y. Endo and S. Tsuru.

The Thickness of Rust Preventive Paints.

S. Yoshida

A New Chromate Treatement and Its Chemistry.

Y. Hisamatsu and K. Mori

Effects of the Additional Lead on the Electrodeposition of Zinc from the Alkaline Zincate Bath. M. Sagara and S. Kawahara

New Types of Surface Treated Steel.

Y. Kitamura (Guest Speaker to the Symposium)

Stress and Other Properties of Chromium Deposits.

S. Konishi

Corrosion of Electroless Nickel Plating Film.

S. Ishibashi, O. Takano and T. Shimizu.

Corrosion and Its Prevention Method of DMH Diesel Engine Injection Nozzle.

A. Fujii and I. Inoue

Corrosion Resistance of Plating in Atomosphere.

Z. Ota and T. Ishikawa

Nickel Plating on Zinc and Zinc Alloys.

T. Inui and K. Hosokawa

Corrosion Resistance $\mathrm{Cu}-\mathrm{Ni}-\mathrm{Cr}$ Electrodeposition.

T. Hayashi, N. Furukawa, Y. Kuwa and T. Ishida

Relative Corrosion Durability of Copper-Nickel-Chromium vs. Duplex Nickel-Chromium Coating. M. Saito and M. Nakamura

Further information will be available from Dr. F. Hine, Dept. of Industrial Chemistry, Kyoto University, Kyoto. 


\title{
THE 31st MEETING
}

of

\section{The Electrochemical Society of Japan}

\author{
University of Kyushu, Fukuoka
}

April 25, 26, 27 and 28, 1964

Sessions will be scheduled on Theoretical Electrochemistry, and Applied Physical Chemistry, Electroorganic, Electroanalysis, Electro-deposition and Surface Treatment, Industrial Electrolytic, Batteries, Corrosion and Prevention, Electronics and Materials for Electrical Industry, Extractive Metallurgy, High Temperature Chemistry and Fused Salts, Electric-discharge Chemistry and Radiation Chemistry, and Instrumentation and Quality Control.

\author{
Saturday, April 25, 1964, $9: 00$ a.m. $-5: 00$ p.m.

\section{Conferences and Invited Lectures}

Sunday, April 26, 1964, $9: 00$ a.m. $-5: 00$ p.m.

\section{Conferences}

Monday, April 27 through Tuesday, April 28, 1964 Excursion

Papers are now being solicited for the 31 st meeting. Duplicate copies of the 200-words abstract are due at Society Headquarters, 3, 1-chome, Yurakucho, Chiyoda-ku, Tokyo, not later than Jan. 31, 1964 in order to be included in the program. Please indicate the title followed by the author's name and business or university connection and underline the name of the author who will present the conference.

Further information will be available from Headquarters, 3,1-chome, Yurakucho, Chiyoda-ku, Tokyo. 